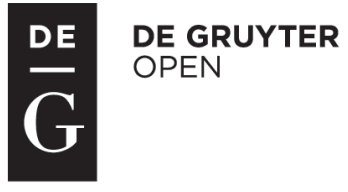

\title{
LEGUME SEEDS AND RAPESEED PRESS CAKE AS REPLACERS OF SOYBEAN MEAL IN FEED FOR FATTENING PIGS*
}

\author{
Ewa Hanczakowska*, Małgorzata Świątkiewicz \\ Department of Animal Nutrition and Feed Science, National Research Institute of Animal Production, \\ 32-083 Balice n. Kraków, Poland \\ •Corresponding author: ewa.hanczakowska@izoo.krakow.pl
}

\begin{abstract}
The possibility of replacing soybean meal with a mixture of legume seeds and rapeseed press cake (RPC) was evaluated on 60 pigs weighing about $30 \mathrm{~kg}$ at the beginning of the experiment. Pigs were allocated to 5 experimental groups. Group I (control) received standard feed mixture containing soybean meal as a main protein source. Next groups received rapeseed press cake (RPC) mixed with fodder pea (Pisum sativum var. Ramrod) - group II, field bean (Vicia faba var. Kasztelan) - group III, blue lupin (Lupinus angustifolius var. Regent) - group IV or yellow lupin (Lupinus luteus var. Mister) - group V. Soybean protein was replaced by experimental protein sources at about $30 \%$ in grower $(17 \%$ legumes, $13 \%$ rapeseed press cake) and at $100 \%$ in finisher diets (experimental proteins in equal ratio accounted for about 55\% of mixture protein). Limited feeding was used, water was available ad libitum. Half the animals in each group received mixtures supplemented with fibrolytic enzymes Ronozyme VP and Ronozyme WX. Apparent digestibility of feed nutrients was estimated using the balance method on 30 fatteners not used in the fattening experiment, weighing about $40 \mathrm{~kg}$ for grower and $70 \mathrm{~kg}$ for finisher diets. Gross composition of legume seeds and RPC, amino acid composition of their protein, glucosinolate content in RPC and tannin content in faba bean and alkaloids in lupins were analysed. Carcass traits and meat quality were also estimated. Legume protein content ranged from $19.6 \%$ (pea) to $39.8 \%$ (yellow lupin). RPC protein contained more sulphur amino acids than legume protein. There was no significant difference in protein and fat digestibility. Body weight gains of fatteners fed with blue lupin were comparable to controls but significantly lower than those of the remaining groups. Supplemental enzymes improved body weight gains of fatteners receiving field bean. There was no significant difference in carcass traits and meat quality except for sensory analysis. It is concluded that the mixture of RPC and legume seeds can replace soybean meal in fattener feed.
\end{abstract}

Key words: legume seeds, rapeseed press cake, pig fattening, feed enzymes

Soybean meal is the most popular protein source in pig feeding. Other legumes: pea, field bean, lupins and also rape grown in Central and Eastern Europe are less

\footnotetext{
*This study was financed from statutory activity No. 05-2.01.1.
} 
important. About $98 \%$ of commercially available soybean meal is derived from genetically modified plants (Sieradzki et al., 2006). Earlier experiments suggest that genetic modification has no effect on nutritive value of feeds (Padgette et al., 1996; Aurlich et al., 2003) or animal performance and carcass and meat quality (Flachovsky et al., 2005). Also our experiments have shown that feeds containing genetically modified soybean and corn had no effect on pig fattening results. There was also no transfer of transgenic DNA from feed to animal tissues (Świątkiewicz et al., 2011). Despite this, in some countries, including Poland, there is a strong and vocal opposition against using genetically modified plants in farm animal and human nutrition. Therefore, further experiments on alternative protein sources are needed.

Pea, field bean and lupins are plants cultivated in Poland in relatively large amounts. Their common drawback is the low content of sulphur amino acids (methionine and cystine) and the presence of various antinutritional factors. Their content in pea is relatively low, though colourful blooming varieties contain tannins (Canbolat et al., 2007). Tannins also occur in field bean, but due to the breeding work their content was significantly lowered even in colourful blooming varieties (Jezierny et al., 2010). Lupin seeds do not contain phenolic compounds and their alkaloid content was lowered to $0.01 \%$ (Ruiz et al., 1977). Because of this lowering they can substitute soybean meal even in human food (Petterson, 1998).

Digestibility of nutrients may be improved by supplementing feed enzymes. Glucanase, pectinase or hemicelullase decompose polysaccharides present in seed cell walls that account for a significant part of the seed. This increases availability of nutrients for enzymes present in the animal digestive tract.

Rapeseed is cultivated mainly as a source of fat but press cake remaining after pressing of oil (rapeseed press cake) can be a good protein source. Its protein is relatively rich in sulphur amino acids, thus it could be a good supplement to legume seeds. Apart from the low content of methionine in legume seed its intestinal digestibility is low (Partanen et al., 2001). Because rapeseed contains antinutritional factors (mainly glucosinolates), its amount in fattener feed should be limited to about 20\% (Partanen et al., 2006).

Publications on using mixtures of rapeseed and legumes in fattener feeding are scarce. Good results were obtained by Thacker and Qiao (2002). Also Partanen et al. (2006) found that a mixture of field bean and rapeseed press cake produces better results than rapeseed alone. Many experiments on nutritive value of legume seeds (Kasprowicz and Frankiewicz, 2004; Stanek et al., 2010) and rapeseed (Raj et al., 2000; Hanczakowska et al., 2012) were carried out in Poland but information on using both these protein sources together are scarce. Turyk et al. (2003), who compared the effect of rapeseed cake and its mixture with field bean, found that while this mixture was comparable to soybean meal, rapeseed cake alone lowered the results. In the experiment of Sobotka et al. (2010) mixture of rapeseed meal with field pea seeds in growing-finishing pigs gave better results than mixture of rapeseed meal with field bean seeds.

The aim of this experiment was to investigate the effect of replacing soybean meal with a mixture of rapeseed press cake and new varieties of legumes in fattener feeds on their performance and carcass and meat quality. The additional aim was to 
examine the possibility of improving the nutritive value of experimental diets by supplementing them with feed enzymes Ronozyme VP and Ronozyme WX.

\section{Material and methods}

The Second Local Cracow Ethics Committee for Experiments on Animals approved all procedures used in this experiment.

\section{Growth experiment}

The growth experiment was performed on 60 fatteners weighing about $30 \mathrm{~kg}$ at the beginning of the experiment, originating from Polish Landrace (PBZ) sows and a Duroc $\times$ Pietrain boar. Animals were allocated to 5 groups, with 12 pigs per group. Group I (control) was fed with standard mixture based on soybean meal. Group II received the same basal mixture but part of soybean meal was replaced with rapeseed press cake mixed with pea (Pisum sativum var. Ramrod) and in group III with field bean (Vicia faba var. Kasztelan). In groups IV and V a mixture of RPC and seeds of blue lupin (Lupinus angustifolius var. Regent) or yellow lupin (Lupinus luteus var. Mister) respectively, was used. Soybean protein was replaced by experimental protein sources at about 30\% in grower (17\% legumes, $13 \%$ rape) and at $100 \%$ in finisher diets (experimental proteins in equal ratio accounted for about $55 \%$ of mixture protein). Half the animals in each group received mixtures supplemented with fibrolytic enzymes Ronozyme VP and Ronozyme WX, both in amount of $100 \mathrm{mg}$ per $\mathrm{kg}$ of mixture. The mixture of enzymes contained endo- $1,4-\beta$-xylanase (minimum activity $1000 \mathrm{FXU} \mathrm{g}^{-1}$ ), endo-1,3(4)- $\beta$-glucanase (minimum activity 50 $\mathrm{FBG} \mathrm{g}^{-1}$ ), pentosanase, hemicellulase and pectinase. Enzymes were kindly supplied by DSM Nutritional Products Ltd. in Mszczonów, Poland. Rapeseed cake was produced in an on-farm biofuel production plant in the Experimental Station Grodziec Śląski, Poland. Composition of the grower (30-60 kg) and finisher feed mixtures $(60-114 \mathrm{~kg})$ is given in Tables 1 and 2 . Their gross composition is presented in Table 3. Animals were kept in individual pens and individually fed twice a day with restricted feed amounts according to body weight: from $1.6 \mathrm{~kg}$ per day from 30 to $80 \mathrm{~kg} \mathrm{BW}$ and $3.2 \mathrm{~kg}$ above $80 \mathrm{~kg} \mathrm{BW}$. During the trial animals had free access to water.

At the end of the fattening experiment (114 kg of BW) all pigs were slaughtered. After $24 \mathrm{~h}$ of storage at $+4^{\circ} \mathrm{C}$ the quality of carcasses was evaluated according to standard methods used at Pig Performance Testing Stations (Różycki and Tyra, 2010). Samples of longissimus muscle, obtained from the area of the last thoracic and first lumbar vertebrae, were removed for analysis. Acidity of meat was estimated with a CP-411 pH-meter equipped with Metron 12-01 electrode and its colour with a Minolta colorimeter. Water holding capacity was estimated in freshly minced meat according to Grau and Hamm (1953) method. The sensory evaluation of meat after cooking was made on a 5-point scale (1 - worst, 5 - best), using Baryłko-Pikielna (1975) method. 
Table 1. Composition of feed mixtures $\left(\mathrm{g} \mathrm{kg}^{-1}\right)$

\begin{tabular}{c|c|c|c|c|c}
\hline Item & Control & Pea & Field bean & Blue lupin & Yellow lupin \\
\hline
\end{tabular}

\section{Grower feed mixtures}

Soybean meal

Pea cv. Ramrod

Field bean cv. Kasztelan

Blue lupin cv. Regent

Yellow lupin cv. Mister

Rapeseed press cake

Corn (ground)

Wheat bran

Wheat (ground)

Barley (ground)

Rapeseed oil

Dicalcium phosphate

Limestone

Premix grower*

Salt

L-lysine

DL methionine

$\begin{array}{rr}210 & 120 \\ - & 160 \\ - & - \\ - & - \\ - & - \\ - & 80\end{array}$

50

50

$300 \quad 300$

$341.7 \quad 303.9$

20

5

13

5

2.8

2

0.5
120

100

- 10

80

300
358.

358.3

15

5

12

5

2.6

1.6

0.5
120

$-$

100

70

$-$

300

386.7

15

6

12

5

2.6

2.2

0.5
80
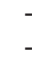

80

70

300

407.6

15

5

12

5

2.6

2.4

0.4

Finisher feed mixtures

Soybean meal

Pea cv. Ramrod

Fidel bean cv. Kasztelan

Blue lupin cv. Regent

Yellow lupin cv. Mister

Rapeseed press cake

Corn (ground)

Wheat bran

Wheat (ground)

Barley (ground)

Rapeseed oil

Dicalcium phosphate

Limestone

Premix finisher**

Salt

L-Lysine

150

$\begin{array}{rr}- & 240 \\ - & - \\ - & - \\ - & - \\ - & 140\end{array}$

60

60

250

436.0

20

2

13

5

2.5

1.5

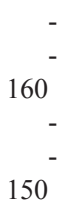

150

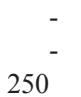

398.2

20

3

11

5

2.5

0.3

$\begin{array}{cc}- & - \\ - & - \\ - & - \\ 110 & - \\ - & 120 \\ 150 & 100 \\ - & - \\ - & - \\ 250 & 250 \\ 430.3 & 491.9 \\ 25 & 25 \\ 4 & 3 \\ 12 & 11 \\ 5 & 5 \\ 2.5 & 2.5 \\ 1.2 & 1.6\end{array}$

*Premix grower: vitamin - $\mathrm{A} 1500000 \mathrm{IU}$; vitamin $\mathrm{D}_{3}-300000 \mathrm{IU}$; vitamin $\mathrm{E}-10.5 \mathrm{~g}$; vitamin $\mathrm{K}_{3}-$ $0.22 \mathrm{~g}$; vitamin $\mathrm{B}_{1}-0.22 \mathrm{~g}$; vitamin $\mathrm{B}_{2}-0.6 \mathrm{~g}$; vitamin $\mathrm{B}_{6}-0.45 \mathrm{~g}$; vitamin $\mathrm{B}_{12}-0.004 \mathrm{~g}$; pantothenic acid $1.5 \mathrm{~g}$; choline chloride $-40 \mathrm{~g}$; biotin $-0.015 \mathrm{~g}$; folic acid $-0.3 \mathrm{~g}$; nicotinic acid $-3.0 \mathrm{~g}$; manganese $-6 \mathrm{~g}$; iodine $0.12 \mathrm{~g}$; zinc $-15 \mathrm{~g}$; iron $-15 \mathrm{~g}$; copper $-4 \mathrm{~g}$; cobalt $-0.06 \mathrm{~g}$; selenium $-0.03 \mathrm{~g}$.

**Premix finisher: vitamin $\mathrm{A}-1000000 \mathrm{IU}$; vitamin $\mathrm{D}_{3}-200000 \mathrm{IU}$; vitamin $\mathrm{E}-7.0 \mathrm{~g}$; vitamin $\mathrm{K}_{3}-$ $0.15 \mathrm{~g}$; vitamin $\mathrm{B}_{1}-0.15 \mathrm{~g}$; vitamin $\mathrm{B}_{2}-0.4 \mathrm{~g}$; vitamin $\mathrm{B}_{6}-0.3 \mathrm{~g}$; vitamin $\mathrm{B}_{12}-0.002 \mathrm{~g}$; pantothenic acid $-1.0 \mathrm{~g}$; choline chloride $-20 \mathrm{~g}$; biotin $-0.01 \mathrm{~g}$; folic acid $-0.2 \mathrm{~g}$; nicotinic acid $-2.0 \mathrm{~g}$; manganese $-4 \mathrm{~g}$; iodine $0.08 \mathrm{~g}$; zinc $-8 \mathrm{~g}$; iron $-10 \mathrm{~g}$; copper $-4 \mathrm{~g}$; cobalt $-0.04 \mathrm{~g}$; selenium $-0.02 \mathrm{~g}$.

\section{Digestibility experiment}

Apparent digestibility was evaluated on 30 fatteners not used in the fattening experiment weighing about $40 \mathrm{~kg}$ for grower diets and $70 \mathrm{~kg}$ for finisher diets. The experimental group consisted of 6 fatteners. Animals were kept individually in bal- 
ance cages and fed with the same feeds as in the fattening experiment. Limited feeding was used, animals received $2.0 \mathrm{~kg}$ (grower) or $3.0 \mathrm{~kg}$ (finisher period) of feed mixture daily. Faeces from each animal were collected daily, weighed and frozen at $-20^{\circ} \mathrm{C}$. At the end of the experiment faeces from all animals from the same group were mixed and the average sample was prepared. Chemical composition of these samples was analysed.

Table 2. Chemical composition of mixtures $\left(\mathrm{g} \mathrm{kg}^{-1}\right)$

\begin{tabular}{l|r|r|r|r|r}
\hline \multicolumn{1}{c}{ Item } & Control & Pea & Field bean & Blue lupin & Yellow lupin \\
\hline \multicolumn{5}{c}{ Grower mixtures } \\
Dry matter & 884.8 & 882.3 & 882.5 & 885.7 & 885.0 \\
Crude protein & 178.8 & 182.4 & 185.4 & 186.8 & 184.6 \\
Crude ash & 46.1 & 50.7 & 47.5 & 45.5 & 47.4 \\
Ether extract & 30.2 & 25.9 & 27.7 & 30.6 & 33.8 \\
Crude fibre & 36.0 & 38.2 & 41.5 & 55.9 & 47.5 \\
Metabolizable energy MJ* & 12.9 & 13.0 & 13.0 & 12.8 & 13.0 \\
& \multicolumn{7}{c}{ Finisher mixtures } & & \\
Dry matter & 881.2 & 878.6 & 878.2 & 879.1 & 881.5 \\
Crude protein & 159.9 & 154.9 & 156.8 & 152.5 & 156.2 \\
Crude ash & 41.9 & 45.7 & 42.2 & 39.0 & 42.4 \\
Ether extract & 30.8 & 36.7 & 27.0 & 37.7 & 43.2 \\
Crude fibre & 37.7 & 44.4 & 37.8 & 43.8 & 50.9 \\
Metabolizable energy MJ* & 13.1 & 13.1 & 13.2 & 13.2 & 13.1 \\
\hline
\end{tabular}

* ME calculated using the equation of Hoffmann and Schiemann (1980).

\section{Chemical analyses}

Chemical composition of legume seeds, rapeseed press cake, feeds and faeces was analysed with the standard methods (AOAC, 2005). Acid detergent fibre (ADF), neutral detergent fibre (NDF) and acid detergent lignin (ADL) were estimated using the Tecator Fibertec System M equipment according to Goering and van Soest (1970) procedures. Glucosinolates content of RPC was determined by HPLC (EN ISO 91-67-1). Tannins content in faba bean was analysed using the vanillin-sulfuric acid method (Kuhla and Ebmeir, 1981) and that of alkaloids in lupins was estimated by gas chromatography according to Gardner and Panter (1993).

Amino acids were determined using HPLC method after acid hydrolysis of samples in $6 \mathrm{~N}$ hydrochloric acid at $110^{\circ}$ during 22 hours in the colour reaction with the ninhydrin reagent using AAA 400 INGOS automatic analyser. Sulfur amino acids were estimated after initial peroxidation with performic acid to cysteic acid and methionine sulfone. Tryptophan content was estimated after alkaline hydrolysis of samples in $\mathrm{BaOH}$ solution and precipitation of barium ions using sulfuric acid.

On the basis of amino acid composition of proteins their nutritive value was estimated. Chemical score (CS) was calculated according to Hidvegi and Bekes (1984) using hen egg protein as a standard. Essential amino acids index (EAAI) was also calculated according to Oser (1951). 
Table 3. Chemical composition $\left(\mathrm{g} \mathrm{kg}^{-1}\right)$ and essential amino acids content of seeds

\begin{tabular}{l|r|c|c|c|c}
\hline \multicolumn{1}{c|}{ Item } & Pea & Field bean & Blue lupin & Yellow lupin & $\begin{array}{c}\text { Rapeseed press } \\
\text { cake }\end{array}$ \\
\hline Dry matter & 855 & 872 & 878 & 881 & 887 \\
Crude protein & 196 & 270 & 276 & 398 & 291 \\
Ether extract & 14 & 9 & 48 & 44 & 137 \\
Crude ash & 28 & 33 & 32 & 34 & 59 \\
Crude fibre & 59 & 72 & 136 & 165 & 119 \\
$\quad$ NDF & 154 & 150 & 211 & 257 & 230 \\
ADF & 79 & 98 & 179 & 205 & 172 \\
ADL & 6 & 7 & 11 & 14 & 63
\end{tabular}

Essential amino acid content $\mathrm{g}$ per $16 \mathrm{~g} \mathrm{~N}$

\begin{tabular}{lccccc} 
Arginine & 9.2 & 7.9 & 10.7 & 11.0 & 5.9 \\
Histidine & 2.3 & 2.0 & 2.8 & 3.7 & 2.5 \\
Isoleucine & 4.3 & 3.4 & 3.8 & 3.3 & 3.5 \\
Leucine & 7.3 & 6.1 & 6.5 & 6.6 & 6.8 \\
Lysine & 7.6 & 5.9 & 4.8 & 4.6 & 6.5 \\
Methionine & 1.1 & 0.9 & 1.0 & 0.6 & 2.9 \\
Phenylalanine & 4.0 & 3.6 & 3.7 & 3.3 & 4.4 \\
Threonine & 3.7 & 3.0 & 3.0 & 2.8 & 4.4 \\
Tryptophan & 1.0 & 0.7 & 0.8 & 0.8 & 1.2 \\
Valine & 4.5 & 3.6 & 3.6 & 3.0 & 4.9 \\
Cystine & 2.1 & 0.8 & 1.2 & 1.5 & 2.1 \\
\multicolumn{1}{c}{ CS Met } & 53.7 & 28.5 & 36.9 & 35.2 & - \\
CS Ile & - & - & - & - & 60.0 \\
EAAI & 80.6 & 66.8 & 69.4 & 65.7 & 84.0 \\
\hline
\end{tabular}

\section{Statistical analysis}

Statistical analysis of treatment effect on pig performance, carcass and meat quality was performed by three-way analysis of variance, including experimental factors: legume type, enzymes supplementation and sex. Comparison of means was performed with Duncan's multiple range test at $\mathrm{P} \leq 0.05$ and $\mathrm{P} \leq 0.01$ levels of significance. Statistical analysis of treatment effect on apparent digestibility coefficients of feed mixtures was performed by one-way analysis of variance, including experimental factor, the legume type. All analyses were conducted using the Statistica 10 package (StatSoft, 2011).

\section{Results}

Chemical composition of legume seeds varied within broad limits (Table 3). Protein content was the lowest in pea (19.6\%) and the highest in yellow lupin $(39.8 \%)$. Field bean contained the lowest amount of fat $(0.9 \%)$, while the highest content was found in blue lupin (4.8\%). Lupins and RPC contained more fibre and NDF 
and ADF fractions than pea and field bean. RPC contained $23.6 \mathrm{mmol}$ of glucosinolates per $g$ of fat-free DM. Alkaloid content in yellow lupin was $0.03 \%$ and that in blue lupin $0.01 \%$ of dry matter. The low-tannin variety Kasztelan contained $0.04 \mathrm{mg}$ of tannins per $\mathrm{g}$ of dry seeds. Large differences were found in amino acid composition of proteins (Table 3 ). RPC protein contained twice as much sulfur amino acids (5.0 g per $16 \mathrm{~g} \mathrm{~N})$ as lupins (2.1 and $2.2 \mathrm{~g})$ and field bean $(1.7 \mathrm{~g})$ and also more sulfur amino acids than pea protein $(3.3 \mathrm{~g})$. Lysine content in RPC protein was also higher than that in lupins and field bean but about $15 \%$ lower than that of pea protein. Methionine was the limiting amino acid in legume proteins (CS 28.5-53.7) and isoleucine was deficient in rapeseed protein (CS 60.0). Rapeseed protein had the highest EAAI. EAAI was high in pea (80.6) but lower in field bean and lupins (65.7-69.4).

Table 4. Apparent digestibility coefficients of grower and finisher feed mixtures

\begin{tabular}{l|l|l|l|l|l|c}
\hline \multicolumn{1}{c}{ Item } & Control & \multicolumn{1}{c}{ Pea } & Field bean & Blue lupin & Yellow lupin & SEM \\
\hline \multicolumn{7}{c}{ Grower mixtures } \\
Dry matter & $84.6 \mathrm{a}$ & $86.9 \mathrm{~b}$ & $86.6 \mathrm{ab}$ & $84.9 \mathrm{a}$ & $85.5 \mathrm{ab}$ & 0.310 \\
Crude protein & 85.2 & 84.5 & 84.2 & 84.1 & 83.6 & 0.294 \\
Ether extract & 56.4 & 57.3 & 56.6 & 59.8 & 61.2 & 1.383 \\
Crude fibre & $29.1 \mathrm{ab}$ & $38.8 \mathrm{~b}$ & $34.5 \mathrm{ab}$ & $26.5 \mathrm{a}$ & $39.2 \mathrm{~b}$ & 1.738 \\
N-free extractives & $87.8 \mathrm{~A}$ & $90.5 \mathrm{~B}$ & $90.2 \mathrm{~B}$ & $88.9 \mathrm{AB}$ & $88.9 \mathrm{AB}$ & 0.287 \\
\multicolumn{7}{c}{ Finisher mixtures } \\
Dry matter & $84.6 \mathrm{Aa}$ & $85.6 \mathrm{ABab}$ & $87.0 \mathrm{Bb}$ & $84.7 \mathrm{Aa}$ & $85.0 \mathrm{ABa}$ & 0.280 \\
Crude protein & 83.7 & $83.0 \quad 67.3$ & 83.8 & 82.1 & 82.1 & 0.336 \\
Ether extract & 68.9 & 67.3 & 61.5 & 69.5 & 69.5 & 1.265 \\
Crude fibre & 32.4 & 40.8 & 38.4 & 39.9 & 39.9 & 1.275 \\
N-free extractives & $88.7 \mathrm{Aa}$ & $90.0 \mathrm{Ac}$ & $91.4 \mathrm{Bd}$ & $89.6 \mathrm{Ab}$ & $89.6 \mathrm{Ab}$ & 0.218 \\
\hline
\end{tabular}

$\mathrm{a}, \mathrm{b}-$ mean values in the same rows with different letters differ statistically at $\mathrm{P} \leq 0.05$.

$\mathrm{A}, \mathrm{B}-$ mean values in the same rows with different letters differ statistically at $\mathrm{P} \leq 0.01$.

There were no significant differences in digestibility of the most important nutrients: protein and fat (Table 4). Such differences were found only in the case of dry matter and $\mathrm{N}$-free extractives. There were also some differences in digestibility of fibre in the first phase of the experiment (grower).

In the first experimental period fatteners fed the mixture of RPC and blue lupin grew slower than the others (Table 5) and the difference was significant when compared to animals receiving pea $(\mathrm{P} \leq 0.05)$ and field bean $(\mathrm{P} \leq 0.01)$. This difference increased and during the whole experiment body weight gains of fatteners fed with blue lupin were comparable to those of control animals but significantly $(\mathrm{P} \leq 0.01)$ lower than those of the remaining groups. The highest feed utilization was found in animals receiving RPC and field bean and the lowest in those fed RPC and blue lupin, but during the whole fattening period these differences were not statistically significant. The enzyme supplement generally had no effect on fattener performance but in the case of field bean it significantly improved body weight gains. Gilts grew more slowly than barrows $(\mathrm{P} \leq 0.05)$ and consumed more feed per $\mathrm{kg}$ of body weight gain $(\mathrm{P} \leq 0.05)$. 


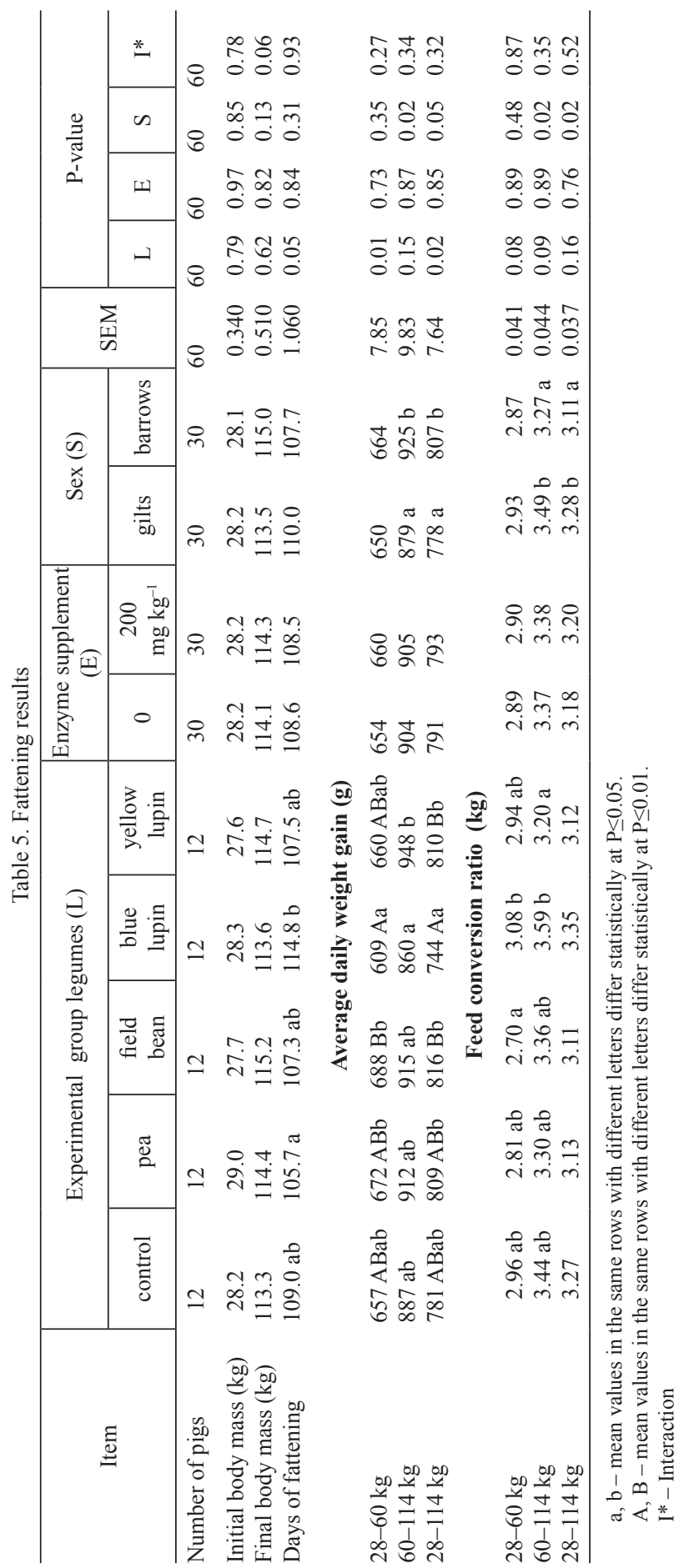




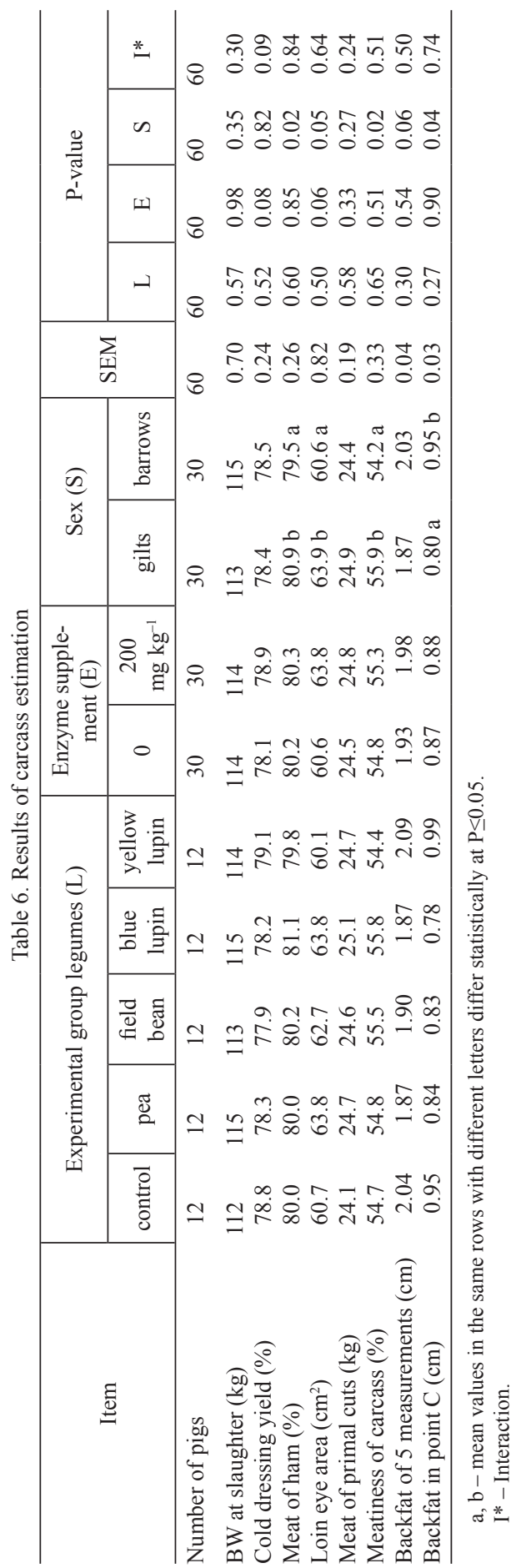




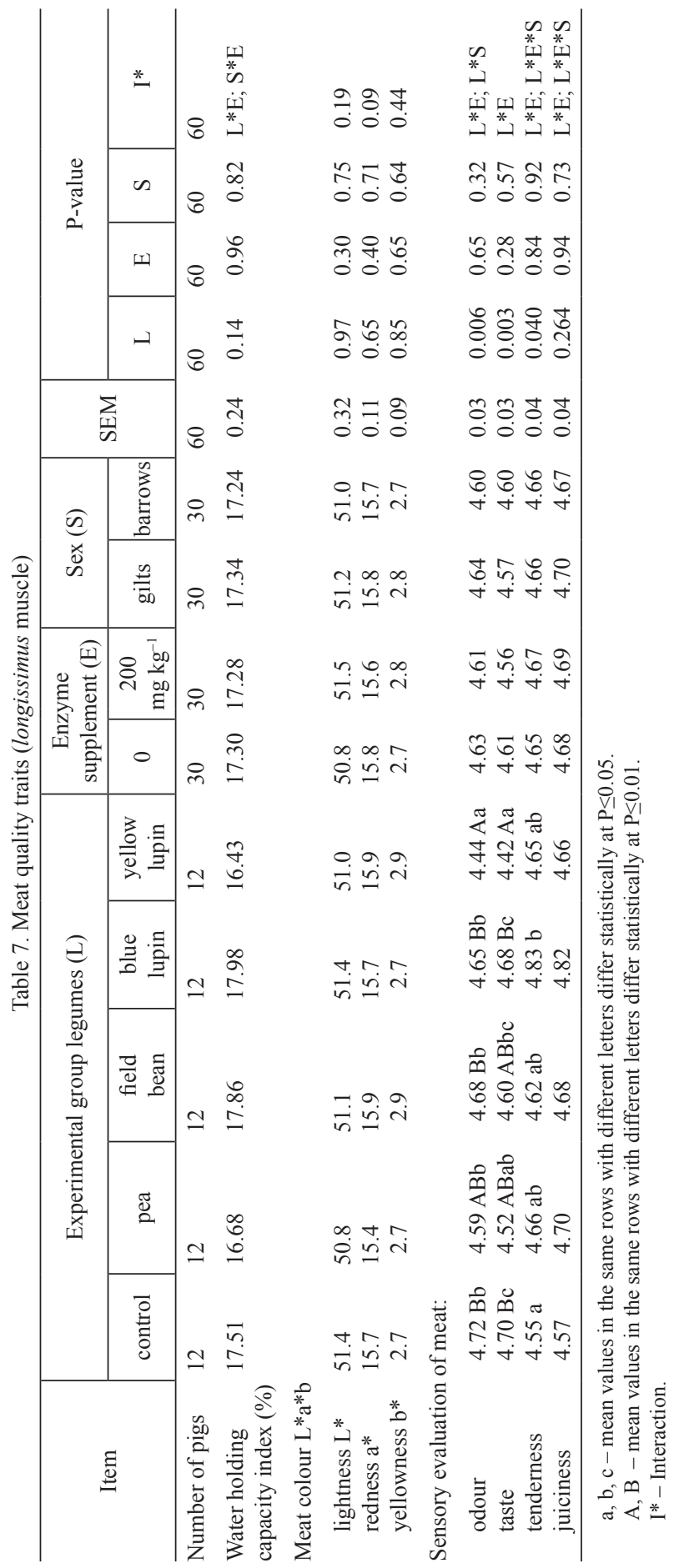


Different legumes and enzyme supplement had no effect on carcass and meat quality (Tables 6 and 7). Carcasses of gilts and their hams contained more meat and had larger loin eye area $(\mathrm{P} \leq 0.05)$.

The type of legume seed or enzyme preparation included in the pig diet did not affect the quality of meat (Table 7). Water holding capacity and colour were similar in all groups. The tested legume seeds had no detrimental effect on the organoleptic characteristics of meat. Sensory evaluation of meat from animals fed the mixture containing yellow lupin revealed significantly poorer smell and taste $(\mathrm{P} \leq 0.01)$ compared to that from pigs fed blue lupin and control ones.

\section{Discussion}

Rapeseed press cake used in this experiment probably had no harmful effect on animal performance. This was shown by the best body weight gains of fatteners fed the highest amount of RPC (15\%) in mixture with field bean in the second part of the experiment. Similarly high body weight gains were obtained when weaned piglets were fed the same low-tannin field bean and RPC mixture (Hanczakowska and Świątkiewicz, 2013). In our earlier experiment (Hanczakowska and Węglarzy, 2012) on fatteners receiving RPC from the same source we did not find lowering of fattening results compared with soybean meal. This is not in accordance with the results of Schöne et al. (2001), who also fed RPC at 15\% of feed and received poorer results than those obtained with soybean meal. On the other hand we must remember that RPC is not a standardized product and batches produced under different conditions may differ significantly.

Protein content of Ramrod pea used in this experiment was relatively low (19.6\%). In the experiment of Igbasan et al. (1997) protein content of different varieties of pea ranged from 20.7 to $26.4 \%$. Also Partanen et al. (2001) found higher protein content in pea and also in field bean (from 32 to 34.7\%), but lower content in blue lupin $(22 \%)$. Also our yellow lupin had higher protein content than those reported by Sudzinova et al. (2009) and Martinez-Villaluenga et al. (2006). According to these last authors protein content in lupins and other legume seeds depends on their variety and cultivating conditions. Because the amount of seeds in feed depends on their protein content, pigs receive different amounts of legumes in different experiments, which had to affect the results.

The amino acid composition of protein of the tested seeds was similar to that quoted by Schumacher et al. (2011). Chemical evaluation of protein quality confirmed that methionine is the limiting amino acid in legume proteins and isoleucine is deficient in rapeseed protein. Differences in CS and EAAI had no effect on pig daily weight gains, which was probably due to the fact that not individual proteins but their mixtures were given. Differences in amino acid composition of protein of various legume varieties are generally small because yield, protein and antinutritive substances content are the main object of interest of plant breeders and amino acids are of secondary importance (Wang et al., 2003). 
The only small (non-significant) differences in fat digestibility found in this experiment are in accordance with results of Jorgensen et al. (2000) and Duran-Montgé et al. (2007) who found no significant differences in fat digestibility in pigs.

Differences in fibre digestibility were found only in the first period of the experiment which could be due to the fact that older animals have better developed digestive tract (Guilloteau et al., 2010) and thus can digest fibre more efficiently.

The available literature contains little information concerning the utilization of mixtures of rapeseed and legumes. Turyk et al. (2003) found slightly better performance of fatteners fed a mixture of RPC and pea compared to those fed soybean meal but RPC fed alone gave significantly poorer results. There was no difference in carcass and meat quality but thyroids of animals receiving the mixture were twice as large as those fed soybean. Similar diets (mixture of rapeseed meal and pea) were used by Stanek et al. (2007). Body weight gains of fatteners receiving this mixture were significantly higher than those of pigs fed with control diet (soybean). Pea alone lowered weight gains, which increased again after supplementing the feed with enzyme having ß-glucanase, xylanase and cellulase activity. According to the authors, the good effect of the mixture was due to the complementary amino acid composition of rapeseed and legumes.

In the experiment of Partanen et al. (2006) RPC in fattener feed was partially replaced with blue lupin seeds. Best results were obtained when the replacement was $33 \%$. Higher amount of lupin lowered weight gains, which probably resulted from lower feed consumption. Also in this experiment no difference in carcass and meat quality was found except for softer fat in animals fed the higher amount of lupin. This was probably due to relatively high content of unsaturated fatty acids in lupin oil.

In conclusion, mixtures of rapeseed press cake with legume seeds, used in the first fattening period at about $30 \%$ of protein level and at $100 \%$ in finisher period, can replace soybean meal in fattening pigs without lowering body weight gains and carcass and meat quality. Blue lupin can be used with caution.

\section{References}

AOAC (2005). Association of Official Analytical Chemists, Official Methods of Analysis. 18th Edition by AOAC International, Revision II 2007, USA.

Aurlich K., Bohme H., Daenicke R., Halle L.T., Flachovsky G. (2003). Genetically modified feeds in animal nutrition. Bacillus thuringiensis $(\mathrm{Bt})$ corn in poultry, pig and ruminant nutrition. Arch. Anim. Nutr., 54: 183-195.

B aryłk o-Piki elna N. (1975). Outline of Food Sensory Analysis (in Polish). WNT, Warsaw, pp. 483.

Canbolat O., Tamer E., A cigkoz E. (2007). Chemical composition, metabolizable energy and digestibility in pea seeds of differing testa and flower colors. J. Biol. Environ. Sci., 1: 59-65.

Duran-Montgé P., Lizardo R., Torrallardona D., Esteve-Garcia E. (2007). Fat and fatty acid digestibility of different fat sources in growing pigs. Livest. Sci., 109: 66-69.

F l a c h ow s k y G., Che s s on A., A u r l i c h K. (2005). Animal nutrition with feeds from genetically modified plants. Arch. Anim. Nutr., 59: 1-40. 
G a r d n e r D.R., P a n t e r K.E. (1993). Comparison of blood plasma alkaloid levels in cattle, sheep and goats fed Lupinus caudatus. J. Nat. Toxins, 2: 1-11.

G o e r ing H.K., Van S o e s t P.J. (1970). Forage Fiber Analyses. Agric. Handbook U.S. Department of Agriculture, p. 379.

Gra u R., H a m m R. (1953). Eine einfache Methode zur Bestimmung der Wasserbindung im Muskel. Naturwissenschaften, 40, p. 29.

Guilloteau P., Zabiels ki R., Hammon H.M., Metges C.C. (2010). Nutritional programming of gastrointestinal tract development. Is the pig a good model for man? Nutr. Res. Rev., 23: 4-22.

Hanczakowska E., Świ ątkiewicz M. (2013). Legume seeds and rapeseed press cake as replacers of soybean meal in sow and piglet feed. Agricult. Food Sci., 22: 435-444.

Hanczakowska E., W ęg larzy K. (2012). Rapeseed press cake in pig fattening diets supplemented with iodine, xylanase or phytase (in Polish). Rocz. Nauk. Zoot., 39: 105-117.

Hanczakowska E., W ęg larzy K., B ereza M. (2012). Effectiveness of rapeseed press cake (RPC) in sow feeding in two reproduction cycles. Ann. Anim. Sci., 12: 95-104.

H i d v e g i M., B e k e s F. (1984). Mathematical modeling of protein quality from amino acid composition. Processing of the International Association of the Cereal Chemistry Symposium, (IACCS 84 ), Akademia, Kiado, Budapest, pp. 205-208.

H o ff m a n n L., S c h i e m a n n R. (1980). Von der Kalorie zum Joule: Neue Grössenbeziehungen bei Messungen des Energieumsatzes und bei der Berechnung von Kennzahlen der energetischen Futterbewertung. Arch. Tierernähr.. 30: 733-742.

I g b a s a n F.A., G u e n t e r W., S 1 o m in s k i B.A. (1997). Field peas: chemical composition, energy and amino acid availabilities for poultry. Can. J. Anim. Sci., 77: 293-300.

Jezierny D., Mos enthin R., B a u e r E. (2010). The use of grain legumes as a protein source in pig nutrition: a review. Anim. Feed Sci. Technol., 157: 111-128.

J orge ne s e n H., G a b e r t V.M., H e d e ma n n M.S., J e n s e n S.K. (2000). Digestion of fat does not differ in growing pigs fed diets containing fish oil, rapeseed oil or coconut oil. J. Nutr., 130: $852-857$.

K a s prow i c z M., Franki ew i c z A. (2004). Apparent and standardized ileal digestibility of protein and amino acids of several field bean and pea varieties in growing pigs. J. Anim. Feed Sci., 13: $463-473$.

K uhl a S., Eb m e ir C. (1981). Untersuchungen zum Taningehalt in Ackerbohnen. Arch. Tierernahr., 31: 573-588.

Martinez-Villaluenga C., Frias J., Vidal-Valverde C. (2006). Functional lupin seeds (Lupinus albus L. and Lupinus luteus L.) after extraction of $\alpha$-galactosides. Food Chem., 98: 291-299.

O s e r B.L. (1951). Method for integrating essential amino acid content in the nutritional evaluation of protein. J. Am. Diet Assoc., 27: 396-399.

Padget te S.R., Taylor N.B., Nida D.L., B a iley M.R., MacDonald J., Hold en L.R., F u s c h R.L. (1996). The composition of glyphosate-tolerant soybean seeds is equivalent to that of conventional soybeans. J. Nutr., 126: 702-716.

Partanen K., Valaja J., Ja lava T., Siljander-Rasi H. (2001). Composition, ileal amino acid digestibility and nutritive value of organically grown legume seeds and conventional rapeseed cakes for pigs. Agric. Food Sci. Finl., 10: 309-322.

Partanen K., Siljander-Rasi H., Alaviuhkola T. (2006). Feeding weaned piglets and growing-finishing pigs with diets based on mainly home-grown organic feedstuffs. Agric. Food Sci., 15: 89-105.

P e t ters o n D.S. (1998). Composition and food uses of lupins. In: Lupins as Crop Plants: Biology, Production and Utilization,. Gladstones J.S., Atkins C.A, Hamblin J. CAB International, Wallingford, pp. 353-384.

Raj S., Fandrejews ki D., Weremko G., Skiba G., Buraczews k a L., Żebrows ka T., H a n I.K. (2000). Growth performance, body composition and protein and energy utilization of pigs fed ad libitum diets formulated according to digestible amino acid content. Asian-Aus. J. Anim. Sci., 13: 817-823.

Róży cki M., Tyra M. (2010). The procedure of pig fattening and slaughter value estimation at 
Swine Performance Testing Stations. In: Report on pig breeding in Poland (in Polish). NRIAP, Kraków, XXVIII: 93-112.

R u i z L.P. Jr., W h i t e S.F., H o v e E.L. (1977). The alkaloid content of sweet lupin seed used in feeding trial on pigs and rats. Anim. Feed Sci. Technol., 2: 59-66.

Schöne F., Tischendorf F., Leiterer M., Hartung H., Bargholz J. (2001). Effects of rapeseed-press cake glucosinolates and iodine on performance, the thyroid gland and the liver vitamin A status of pigs. Arch. Tierernahr., 55: 333-350.

S c h u m a ch er H., P a u l s e n H.M., G a u A.E., L in k W., Jörg en s H.U., S a s s O., D i e ter $\mathrm{i} \mathrm{ch}$ R. (2011). Seed protein amino acid composition of important grain legumes Lupinus angustifolius L., Lupinus luteus L., Pisum sativum L. and Vicia faba L. Plant Breeding, 130: 156-164.

S i e r a d z k i Z., W a l c z a k M., K w i a te k K. (2006). Occurrence of genetically modified maize and soybean in animal feedingstuffs. Bull. Vet. Inst. Pulawy, 52: 567-570.

S o b otk a W., D ra zbo A., S t a n e k M. (2010). Effect of the source of vegetable dietary protein on nitrogen excretion to the environment in growing-finishing pigs. Ecol. Chem. Engin., 17: 657-663.

S t a n e k M., P u rw in C., B i en i a s zew sk i T. (2007). Effect of feeding diets containing pea seeds and rapeseed cake or feed enzymes on the fattening results of pigs (in Polish). Zesz. Probl. Post. Nauk Roln., 522: 419-425.

Stanek M., B o gus z J., S o b otk a W. (2010). Nutrient digestibility and nitrogen balance in fattening pigs fed diets containing blue lupine (Lupinus angustifolius) seeds. Ecol. Chem. Engin., A 17: 671-676.

Sudzinova J., Chrenkova M., Čeresnakova Z., Mlnekova Z., Tomikova A. (2009). Effect of lupine and field pea on growth parameters and nitrogen balance in rats. Slovak J. Anim. Sci., 42: 107-110.

Świątkiewicz M., Hanczakowska E., Twardowska M., Mazur M., Kwiatek K., Kozaczyński W., Świą tkiewicz S., Sieradzki Z. (2011). Effect of genetically modified feeds on fattening results and transfer of transgenic DNA to swine tissues. Bull. Vet. Inst. Pulawy, 55: 121-125.

Tha ck e r P.A., Q i a o S. (2002). Performance, digestibility, and carcass characteristic of growing/ finishing pigs fed barley-based diets supplemented with an extruded or unextruded blend of peas and canola seed or meal. Asian-Aust. J. Anim. Sci. 15, 102-105.

T u ry k Z., O s e k M., K l o c e k B., W it a k B. (2003). The effect of protein feeds on fattening results and post-slaughter evaluation in swine. Pol. J. Food Nutr. Sci., 12/53: 63-67.

Wang T.L., D o mon e y C., Hedle y C.L., C a s e y R., Grusak M.A. (2003). Can we improve the nutritional quality of legume seeds? Plant Physiol., 131: 886-891.

Received: 25 IV 2014

Accepted: 1 VIII 2014 